Click www.researchjournal.co.in/online/subdetail.html to purchase.

A

\title{
Rевенсн автіске: Bioefficacy of certain acaricides against chilli mite, Polyphagotarsonemus latus
}

\section{P.M. SANGLE, MITHU ANTU, S.R. PAWAR, D.G. PANPATTE AND D.M. KORAT}

Article Chronicle: Received :

15.07.2017;

Accepted :

30.07.2017

KEY Words:

Fenpyroximate,

Diafenthiuron,

Acaricides, Chillimite
SUMMARY : Investigation on bio efficacy of certain newer acaricides against chilli mite, Polyphagotarsonemus latus Banks was carried out at Main Vegetable Research Station, Anand Agricultural University, Anand (Gujarat) during Kharif and Rabi 2013. Results revealed that fenpyroximate $(0.005 \%)$ significantly suppressed the mite followed by diafenthiuron $(0.06 \%)$. Both these acaricides registered significantly low incidence ( 7.85 to 8.74 mites/3 leaves) of the pest as compared to rest of the acaricides. Fenazaquin stood at third position next to fenpyroximate and diafenthiuron. Spiromesifen $(0.02 \%)$ and fenpropathrin $(0.018 \%)$ found moderately effective against $P$. latus. Plots treated with fenpyroximate produced significantly highest $(105.80 \mathrm{q} / \mathrm{ha}$ ) green chilli yield than rest of the treatments. Increase in yield over control was highest $(74.92 \%)$ in fenpyroximate followed by diafenthiuron, fenazaquin and spiromesifen. Maximum (1:11.87) ICBR was registered in fenpyroximate followed by fenpropathrin (1:11.40) and hexythiazox (1:7.03).

How to cite this article : Sangle, P.M., Antu, Mithu, Pawar, S.R., Panpatte, D.G. and Korat, D.M. (2017). Bioefficacy of certain acaricides against chilli mite, Polyphagotarsonemus latus. Agric. Update, 12(TECHSEAR5) : 1384-1389; DOI: 10.15740/HAS/AU/12.TECHSEAR(5)2017/1384-1389.
Author for correspondence :

\section{P.M. SANGLE}

Anand Agricultural

University, ANAND

(GUJARAT) INDIA

Email : sangle.pradeep@ gmail.com

See end of the article for authors' affiliations 